\title{
Does the cognitive activity can generate student's physics argumentation performance features?
}

\author{
Viyanti $^{1 *}$, Cari ${ }^{2}$, Zuhdan Kun Prasetyo ${ }^{3}$, Hervin Maulina ${ }^{4}$ \\ ${ }^{1,4}$ Physics Education Study Programe, Universitas Lampung, Bandar Lampung, Lampung, Indonesia \\ ${ }^{2}$ Science Education Study Programe, Universitas Sebelas Maret, Surakrta, Indonesia \\ ${ }^{3}$ Science Education Study Programe, Universitas Negeri Yogyakarta, Yogyakarta, Indonesia
}

*Corresponding Address: viyanti.1980@fkip.unila.ac.id

\begin{tabular}{|c|c|}
\hline Article Info & ABSTRACT \\
\hline Article history: & \multirow{6}{*}{$\begin{array}{l}\text { A performance feature is a domain-specific to the organization of knowledge. } \\
\text { Well-organized knowledge is characterized when students can collaborate } \\
\text { with the knowledge features of the physics problem. The knowledge feature } \\
\text { can be a cognitive activity where teachers influence students by changing the } \\
\text { pattern of knowledge from "defining" to "applying" knowledge. This research } \\
\text { aims to analyze whether the cognitive activity from the teacher can generate } \\
\text { student's argumentation performance features or not. This study is a } \\
\text { qualitative descriptive study that involved } 100 \text { high school students in Bandar } \\
\text { Lampung. The data was collected using a research instrument in the form } \\
\text { of reasoned multiple choices which has been validated. The results of this } \\
\text { study showed that students' involvement in cognitive activity by following a } \\
\text { variety of procedures can generate student's argumentation performance } \\
\text { features. }\end{array}$} \\
\hline $\begin{array}{l}\text { Received: February } 24^{\text {th }}, 2020 \\
\text { Accepted: April } 28^{\text {th }}, 2020\end{array}$ & \\
\hline Published: April 30 $30^{\text {th }}, 2020$ & \\
\hline Keywords: & \\
\hline $\begin{array}{l}\text { Performance argumentation; } \\
\text { Cognitive activity; }\end{array}$ & \\
\hline $\begin{array}{l}\text { Physics problem } \\
\text { Pal }\end{array}$ & \\
\hline
\end{tabular}

(C) 2020 Physics Education Department, UIN Raden Intan Lampung, Indonesia.

\section{INTRODUCTION}

Cognitive activity is naturally shaped through the process of training in the classroom. This means that students' cognitive activities must be supported by learning that develops an understanding of how data is used to build, evaluate, and revise knowledge. Some experts revealed that: (1) maximizing the use of the classroom environment gives students opportunities to be involved in the scientific process (NRC, 2012). (2) the efforts to incorporate scientific activities into classroom learning activities can strengthen student knowledge (Schwarz et al., 2017). (3) science learning means that learning requires students to interact with each other in a new way (Guzey et al., 2017; Johnson et al., 2016; Osborne, 2010). and (4) the classroom environment becomes a learning environment that places students as science performers (Miller et al., 2018). But in reality, students have difficulty getting meaningfully involved in science learning due to the demand to be active in learning (Miller et al., 2018; Murphy et al., 2019; Sampson et al., 2011). Ideally, the experience of changing knowledge systems and the process of changing knowledge is the basis for generating new knowledge in learning.

Science learning requires a lot of learning experience. Teachers need to formulate cognitive activities that can facilitate learning experiences that enable students to practice science. Each study revealed that the center of the power of learning lies in the dynamics of knowledge, where students are positioned as agents that produce learning experiences (Miller et al., 2018). This means the teacher has a role in formulating the dynamics of knowledge to organize students' knowledge 
in the form of argumentation performance features. The dynamics of knowledge require students to engage in diverse learning and make performance arguments (condition competition and ideas as a process of understanding concepts) (McNeill et al., 2017; Stanford et al., 2016). Performance argumentation plays an important role in how scientific knowledge is generated and revised in learning (Osborne, 2010). It was further revealed that developing student argumentation performance involved students (asking each other questions) to uncover and develop the concept of knowledge (Hsu et al., 2019; JiménezAleixandre \& Eruran, 2008). This means that through argumentation performance features, the target of the learning process allows students to acquire and generalize knowledge using the features set by the teacher. Many research revealed that the teacher has a role in determining how students interact during learning (Mortimer \& Scott, 2003).

Most of the researcher has been focused their study on student's argumentation in science education (Martins \& Justi, 2019; Khishfe, 2014; McDobald \& McRobbie, 2010) and the difficulties of the teachers to build up and organizing productive arguments in the classroom (McNeill \& Pimentel, 2010). Recently, the study of students' science argumentation skills has only focused on applying the sociocultural framework through discussion of science material with students in the class (Sandoval et al., 2019). However, no research shows how to produce performance features of student argumentation through tests, which then becomes the reason why this research should be done. The new findings from this test are questions that consist of cognitive activity that allows students to explore in-depth their answers step by step.

The argumentation performance feature can limit the types of contributions students can make during learning and help teachers assess students' conceptual knowledge. The indicators of argumentation performance features in this study are statement information models containing the characteristics of an understanding of concepts and network models of concept representation. With this feature, students can collaborate with friends to carry out the process of learning science. Argumentation performance features facilitate students to construct new ideas and knowledge (Ford, 2012; Wingate, 2019). In line with the opinion which states that building and debating scientific understanding can allow students to interact with friends (Schwarz et al., 2017). This means that the fulfillment of the argumentation performance feature is an implementation of science learning reform (Viyanti et al., 2016). Based on this, the purpose of this study is to analyze whether a cognitive activity can produce student argumentation performance features or not?

The argumentation performance features in this study are outlined in the application of the test by providing stimulus and continuous training. The choice of the assessment system in analyzing the argumentation performance features profiles is because the assessment acts as feedback for the teacher to be able to improve the quality of the argumentation performance indicators leading to the achievement of the argumentation performance features.

\section{METHODS}

To find out the profile features of student performance arguments, the qualitative descriptive research method was used in this study. The sample selection method uses purposive sampling involving 100 high school students in Bandar Lampung City, Lampung, Indonesia. The data was collected using a valid and reliable research instrument in the form of an essay test with a total of 10 questions, which were constructed based on student performance argumentation indicators. Validity and reliability test for the instrument used Rasch Model with Ministep 4.5.1 software. The average score of validity test has outfit Z-standard of 1.93 (accepted). Besides, the reliability test has the average 
value of INFIT MNSQ and OUTFIT MNSQ of 0.95 , the average value of INFIT ZSTD, and OUTFIT ZSTD of -0.11 (good person quality), and the value of person reliability is 0.95 . This value showed that the consistency of the answers was very good, which means that all the respondence answered the test seriously (Bone et al., 2014).

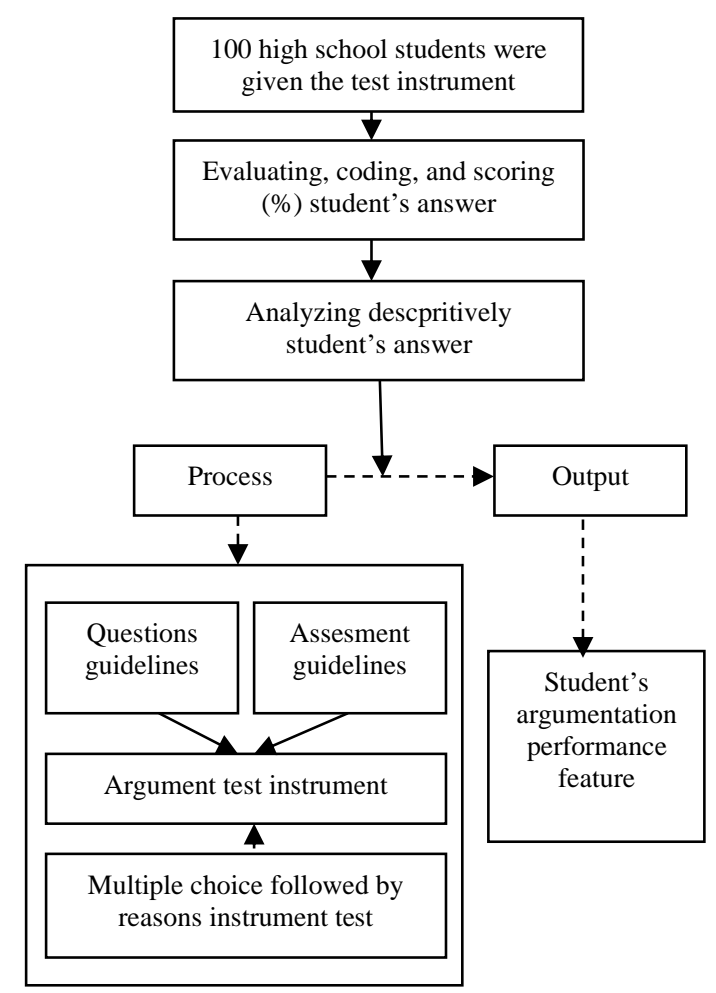

Figure 1. The Stages of Analyzing Student's argumentation performance feature

The data that has been collected is scoring and calculating the average student who answers right and wrong. After the percentages are performed, the next stage is analyzed descriptively. Based on Viyanti (2019), the description of argumentation performance features leads to the ability of students to (1) work on understanding concepts, (2) consolidate and explore concepts, and (3) elaborate on different statements of each problem as an effort to conceptual change. The whole process of this study can be summarized in Figure 1 . Besides that, the indicators of cognitive activity are 1) statement information, 2) network model representation concept, and 3) elaboration between concept and statement.

\section{RESULTS AND DISCUSSION}

Teachers play a role in creating a classroom environment that supports student argumentation interactions (Evagorou \& Dillon, 2011). As a result, it is important to analyze the way the teacher fosters a learning environment in which argumentation performance features to be one approach to stimulate students' cognitive organizing. After evaluating and coding the score of each cognitive activity indicators, the next step is scoring the student's answer. The average percentage of student's argumentation performance features is $72.35 \%$. It means that argumentation performance features have been generated. For detailed score in each indicator can be seen from Table 1 .

Table 1. The average score of each indicator of cognitive activity

\begin{tabular}{|l|l|}
\hline \multicolumn{1}{|c|}{ Cognitive activity indicators } & $\begin{array}{c}\text { Average score } \\
(\boldsymbol{\%})\end{array}$ \\
\hline Statement information & 25.12 \\
\hline Network model representation concept & 23.77 \\
\hline Elaboration between concept and statement. & 23.46 \\
\hline Total Score & $\mathbf{7 2 . 3 5}$ \\
\hline
\end{tabular}

The results of the analysis utilizing the performance features of the argument are explained as follows,
The information model statements contain the characteristics of understanding concepts

Figure 2 represents the statement information model that contains the characteristics of an understanding of the 
concept. Based on these problems, students are asked to pay attention to two toy cars that travel along the $2 \mathrm{~m}$. Basically, the teacher expects students to categorize concepts that must be produced by raising the problem of which car is faster. The problems proposed by the teacher can be solved well by students by submitting answer statements. The following are examples of student's answer,

"Red car, because even though the red car has a longer distance than the blue one, they stop at the same time",

Which car goes faster?
A. Blue Car
B. Red Car
C. Both have the same speed
Student's answer:
Red car, because even though the red car has
the longer distance than the blue one, they stop
at the same time

Figure 2. The example of the information statement model contains the characteristics of understanding the concept

The answers represent students' ability to unite every element of the concept that has certain similarities. If we see from Figure 2, students should analyze and predict the relation between velocity, time, and distance.

Another discussion based on Figure 2, the students' ability to fulfill the process of scientific understanding enables students to produce their investigation statements with stimulated curiosity and driven deep thinking to find the characteristics of the relationship between problems, clues, evidence/data, and conclusions. Student analysis can be presented sequentially (Creswell et al., 2003). This means that students have been able to recognize several aspects of the concepts presented by the teacher. For example, student explanation is based on the question in Figure 3.

\footnotetext{
"The blue car starts in front of the red car"
}

The statement is not a concept. Concepts arise when students are able to analyze further such statements,

“... because the red car starts at point 0 while the blue car has gone $20 \mathrm{~cm}$ further"

Furthermore, students are said to be able to express a concept when able to explore and analyze the problem given in Figure 2 and then elaborate the concept in the form of an answer statement. This can be seen from the students' answers in Figure 3, namely the statement,

"... speed affects the distance that will be traveled...."

All of the following statements are true, but which one is the
best explanation for the answer above:
A. Both cars start and stop at the same time
B. Red car travel farther than the blue car at the same time
C. Blue car sarts in front of a red car
Other Reasons:
Student's Answer: The blue car starts in front of the red car
because the red car starts at the initial condition at 0 while
the blue car has already traveled $20 \mathrm{~cm}$ along.
Conclusion:
Student's Answer: the blue car comes first to the red one
because the blue car is $20 \mathrm{~cm}$ in front of the red one.
Velocity affects the distance
V=S/t
which is V $\mathrm{V}=$ velocity
$\quad \mathrm{s}=$ distance
$\mathrm{t}=$ time

Figure 3. The student tries to elaborate on a concept from the previous question

To state an answer, students must be able to explore and analyze problems and possible answers. In addition, each student statement can be combined to form different concepts, for example:

"... the faster the vehicle's speed the closer it is; the further the distance the shorter the time required".

From the answer of student 1 and student 2 , it can be concluded that student 1 has the correct answer. On another hand, even student 2 has an incorrect answer but she/he has brave to try to generate her/his argumentation 
Related to this, the concept is represented by a set of elements or a collection of information that is verified based on relevant theory (consolidation). The ability of students to find statements is an indication of students' steps towards understanding. On the other hand, the statements produced by students make a good source of information for teachers to package feed back. It is very important to encourage students to produce statements and reflect on the process of argumentation performance (Simon et al., 2006).

\section{Network Model Representation Concept}

Figure 4 represents the organization of knowledge through concept network relations. The concept relationships produced by students are indicated by statements,

"The forces acting on the book are the gravity force, and the normal force, the gravity force".

This is reinforced by students' additional information,

"... because there is a force of action and reaction between the book and the table, the book has a weight down and the table gives an upward push so that the book remains silent".

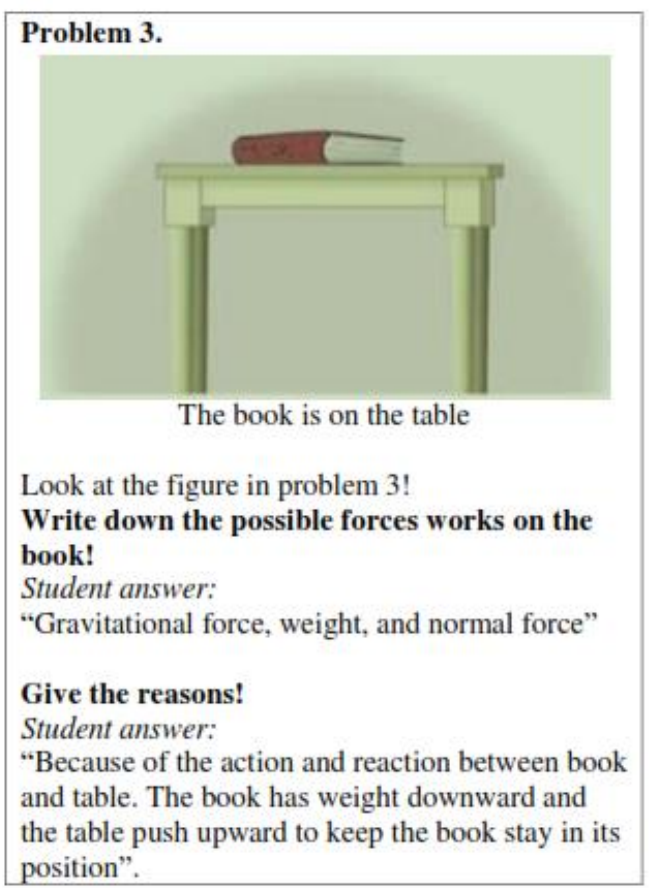

Figure 4. Examples of network representation feature produced by students
The conceptual relationship networks that succeed in producing students explicitly provide information that the whole process requires basic concepts to test the ideas displayed to assess the accuracy of the concepts presented by students. This process allows students to begin to develop the basic concepts of a theory (Marshall \& Rossman, 2015). This is an implication that the organization of concepts presented by students is composed of basic concepts that are related and interconnected. The way the teacher frames the performance features of the argumentation has an impact on how students understand and are involved in understanding a basic concept and that modeling expectations around the use of data encourages students to produce quality statements (Berland \& Hammer, 2015; González-Howard et al., 2017). Above all, this feature provides students the opportunity to provide a stepping stone for further concepts. Students' involvement in organizing knowledge through concept network relationships inherently requires changes in the way of producing statements by students (González-Howard et al., 2017). This means that this step helps the teacher analyze how statements can be coordinated (O’Conner \& Michaels, 1993).

\section{CONCLUSION AND SUGGESTION}

The involvement of students in cognitive activities by following various procedures produces a systematic collection of knowledge about the scientific phenomena of the problems presented have been succeeded to generate argumentation performance feature. It can be seen from each step of the student's answer based on statement information and network model representation concept, even though some students answer incorrectly. Future research needs to assess how to treat a powerful strategy for the students who answer incorrectly to make good interaction with those who answer correctly. So, they will be able to have a deeper understanding of the problems given. 


\section{AUTHOR CONTRIBUTIONS}

$\mathrm{CC}$ led the project and has provided guidance. VV and HM collected data, analysed data and wrote the findings, discussion. ZK displaying design and reviewing literature pertaining to the study.

\section{REFERENCES}

Berland, L. K., \& Hammer, D. (2012). Framing for scientific argumentation. Journal of Research in Science Teaching, 49(1), 68-94.

Boone, W.J., Staver, J.R., \& Yale, M.S. (2014). Rasch Analysis in the Human Science. Springer.

Creswell, J. W., Plano Clark, V. L., Gutmann, M., \& Hanson, W. (2003). Advanced mixed methods research designs. In A. Tashakkori \& C. Teddlie, Eds., Handbook of mixed methods in social and behavioral research. Sage Publications.

Evagorou, M., \& Dillon, J. (2011). Argumentation in the teaching of science. In D. Corrigan, J. Dillon, \& R. Gunstone, Eds., The professional knowledge base of science teaching. Springer.

Ford, M. J. (2012). A dialogic account of sense-making in scientific argumentation and reasoning. Cognition and Instruction, 30(3), 207-245.

González-Howard, M., McNeill, K. L., Marco-Bujosa, L., \& Proctor, C. P. (2017). 'Does it answer the question or is it French fries?': An exploration of language supports for scientific argumentation. International Journal of Science Education, 39(5), 528-547.

Guzey, S. S., Ring-Whalen, E. A., Harwell, M., \& Peralta, Y. (2017). Life STEM: A Case Study of Life Science Learning Through Engineering Design. International Journal of Science and Mathematics Education, 17(1), 23-42.

Hsu, P.-S., Lee, E. M., Ginting, S., Smith, T. J., \& Kraft, C. (2019). A Case Study Exploring Non-dominant Youths' Attitudes Toward Science Through
Making and Scientific Argumentation. International Journal of Science and Mathematics Education, 17(1), 185-207. Jiménez-Aleixandre, M. P., \& Erduran, S. (2008). Argumentation in science education: An overview. In S. Erduran \& M. P. Jimenez Aleixandre, Eds., Argumentation in science education: Perspectives from classroom-based research. Springer.

Johnson, C. C., Peters-Burton, E. E., \& Moore, T. J. (Eds.). (2016). STEM road map: A framework for integrated STEM education. Routledge.

Khishfe, R. (2014). Relationship between nature of science understandings and argumentation skills: A role for counterargument and contextual factors. Journal of Research in Science Teaching, 49(4), 485-514.

Locke, L. F., Spirduso, W. W., \& Silverman, S. J. (2013). Proposals that work: A guide to planning dissertations and grant proposals (6th ed.). Sage Publications.

Martins, M., \& Justi, R. (2019). An instrument for analyzing students' argumentative reasoning when participating in debates. International Journal of Science Education, 41(6), 713-738.

Marshall, C., \& Rossman, G. B. (2015). Designing qualitative research (6th ed.). Sage Publications.

McDonald, C. V., \& McRobbie, C. J. (2010). Utilizing argumentation to teach nature of science. In B. J. Fraser, K. G. Tobin, \& C. J. McRobbie (Eds.), Second international handbook of science education. Springer.

McNeill, K. L., González-Howard, M., Katsh-Singer, R., \& Loper, S. (2017). Moving beyond pseudo argumentation: Teachers' enactments of an educative science curriculum focused on argumentation. Science Education, 101(3), 426-457.

McNeill, K. L., \& Pimentel, D. S. (2010). Scientific discourse in three urban 
classrooms: The role of the teacher in engaging high school students in argumentation. Science Education, 94(2), 203-229.

Miller, E., Manz, E., Russ, R., Stroupe, D., \& Berland, L. (2018). Addressing the epistemic elephant in the room: Epistemic agency and the next generation of science standards. Journal of Research in Science Teaching, 55(7), 1053-1075.

Mortimer, E. F., \& Scott, P. H. (2003). Meaning-making in secondary science classrooms. Maidenhead, England: Open University Press.

Murphy, P. K., Greene, J. A., Allen, E., Baszczewski, S., Swearingen, A., Wei, L., \& Butler, A. M. (2018). Fostering High School Students' Conceptual Understanding and Argumentation Performance in Science through Quality Talk discussions. Science Education, 102(6), 1239-1264.

National Research Council (NRC). (2012). A framework for $k-12$ science education: Practices, crosscutting concepts, and core ideas. The National Academies Press.

O’Conner, M. C., \& Michaels, S. (1993). Aligning academic task and participation status through revoicing: Analysis of a classroom discourse strategy. Anthropology and Education Quarterly, 24(4), 318-335.

Osborne, J. (2010). Arguing to learn in science: The role of collaborative, critical discourse. Science, 328(5977), 463-466.

Sampson, V., Grooms, J., \& Walker, J. P. (2011). Argument-driven inquiry as a way to help students learn how to participate in scientific argumentation and craft written arguments: An exploratory study. Science Education, 95(2), 217-257.

Sandoval, W. A., Enyedy, N., Redman, E. H., \& Xiao, S. (2019). Organizing a culture of argumentation in elementary science. International Journal of Science Education, 41(13), 1-22.

Schwarz, C. V., Passmore, C., \& Reiser, B.J. (2017). Helping students make Sense of The World using Next Generation Science and Engineering Practices. National Science Teachers Association Press.

Simon, S., Erduran, S., \& Osborne, J. (2006). Learning to teach argumentation: Research and development in the science classroom. International Journal of Science Education, 28(2), 235-260.

Stanford, C., Moon, A., Towns, M., \& Cole, R. (2016). Analysis of instructor facilitation strategies and their influences on student argumentation: A case study of a process-oriented guided inquiry learning physical chemistry classroom. Journal of Chemical Education, 93(9), 1501-1513.

Viyanti. (2019). Pengembangan Instrumen Penilaian Keterampilan Berargumentasi untuk Pembelajaran Prinsip Archimedes. Surakarta: UNS. Disertasi.

Viyanti, Cari, Sunarno, W., \& Prasetyo, Z. K. (2016). Pemberdayaan Keterampilan Argumentasi Mendorong Pemahaman Konsep Siswa. Jurnal Penelitian Pendidikan Fisika, 7(1), 43-48.

Wingate, U. (2019). "Can you talk me through your argument"? Features of dialogic interaction in academic writing tutorials. Journal of English for Academic Purposes, 38, 25-35 